\title{
Effects of Hair dyes on Sequence Analysis of Hair Mitochondrial DNA
} Hypervariable Region 1

تأثير اصباغ الثعر على نتائج تحليل التتابعات الوراثية للحمض النووي المايتوكونديري لمنطقة السيطرة Hypervariable Region 1

Halah Khalid Ibrahim Al-Sammarraie

Mohammed M. AL-Zubaidi

Dhuha Salim Namaa Sura Nabeel Hameed Thooalnoon Younes Saleh Haider K. Al-Rubai Dheaa Sh. Zageer *Ala Hazim Bader

Forensic DNA Research and Training Center/ Al-Nahrain University

ذوالنون يونس صالح *Kamal AL- Al-Sammarraie/ Ministry of Health

$$
\begin{aligned}
& \text { سرى نبيل حميد } \\
& \text { ضحى سالم نعمة } \\
& \text { ضياء شامخ زغير }
\end{aligned}
$$

Hala_kh76@yahoo.com

\begin{abstract}
Hair can be a valuable source of DNA especially in forensic casework and for noninvasive studies of human, when blood samples not available. This study emphasizes the impact of hair dyes on DNA sequence analysis. Samples collected from forty Iraqi families; each sample was divided in to two parts hair follicles and hair shaft. DNA extracted by using two different techniques, Phenol-chloroform (organic) method and prepFiler forensic DNA extraction kit. After quantification of DNA by real time PCR to confirm the exact DNA yield, Mitochondrial DNA (MtDNA) hypervariable region 1 successfully amplified from $(50 \%$ of samples include hair follicle and $20 \%$ samples include shaft only), which all extracted by organic method. Whereas by using prepFiler kit the ratio of amplification success reach to 95\% of samples included hair follicles, but there wais no DNA outcome from hair shaft by using this kit. Our results demonstrate that treated hair by dyed or henna had a significant influence on the sequence analysis results. Organic method was an appropriate method for extraction DNA from hair shaft, since this method used for extracting the old and degraded samples. While prepFiler DNA extraction kit was more convenient for isolation DNA from, hair samples included follicles only with excellent result.
\end{abstract}

Keywords: Biological hair sample, Mitochondrial DNA, human identification, degraded samples

الثشع يمكن أن يكون مصدرا قيما للحمض النووي خاصة في الدعاوى القضائية والطب الثرعي وللاراسات البشرية الوراثية التي لا تائوفر

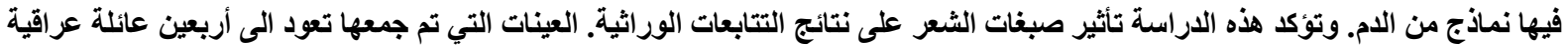

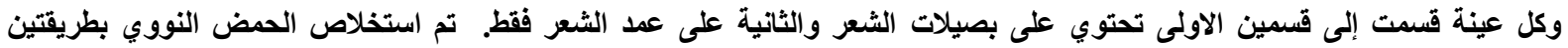

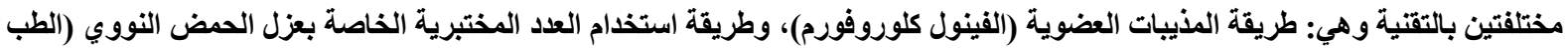

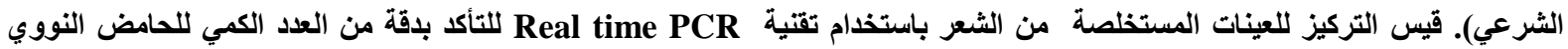

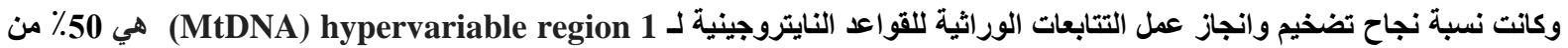

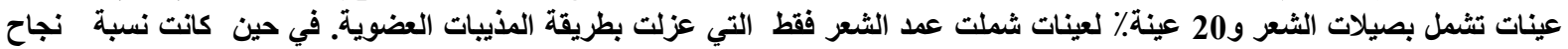

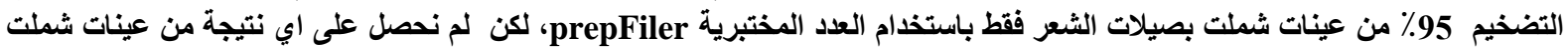

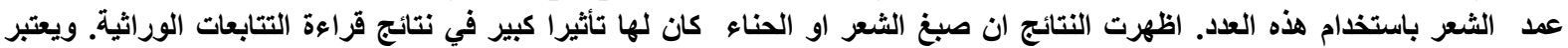

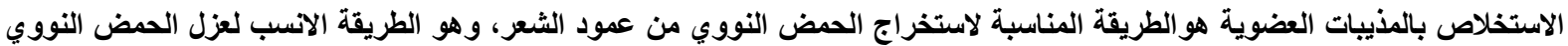
من العينات القايمة و المتدهورة. في حين ان عدد الـ prepFiler أكثر ملاءمة لعزل العمض النيخ النووي من العينات التي شملت بصيلات فقط.

Introduction

The first reported use of forensic human-hair comparison was by Rudolf Virchow in 1861 [1]. Of course, at that time the investigations relied on the microscopic appearance of hair only and could never gain human identification [2]. Nowadays it is indispensable of use human hair in DNA forensic tests analysis for identification because human hair sample is considered as one of the most common biological evidence that can be found in crime scene and it is not easily destroyed because of the tough outer coating of hair [3-5]. Even with exposure to moisture and decomposition of accompanying tissue [6,7]. The tools of molecular biology have qualified the scientists to analyze hair from crime scene, if hair sheath material contains a root material, this hair should subjected to nuclear DNA analysis (STR profile) which is best for the comparison of a questioned sample (crime scene or human remains) with a reference sample (suspect) $[8,9]$. 
Mitochondrial DNA (MtDNA) has several features that can make it useful marker for human identification; usually resort to its marker when nuclear DNA marker fails to give a reliable result [10], such as the cases of the degraded samples or skeletal remains or hair without root [11,12]. It exhibits some advantages over nuclear DNA analysis in such cases like handers to thousands of copies of MtDNA present in a cell (depend on the type of cell) compared to 2 copies of nuclear DNA, and its maternally inherited [10]. The high copy number of the mitochondrial genome often means that mtDNA data can be reliably generated even when attempts to type nuclear DNA markers fail to produce a profile, but still this test has low power of discrimination, labor intensive and expensive[13,14].

MtDNA was a closed circular molecule with a certain region related to forensic analysis and located in control region of mtDNA were highly variable among individuals [7]. This sequence variation was within two hypervariable (HV) regions HV1 and HV2 [15]. Hairs contain extremely small quantities of DNA making the methods used extract the DNA of major importance [10]. The aim of this work was to analyze the MtDNA sequences of hairs subjected to dyes for forensic application.

\section{Materials and Methods \\ Sample Collection}

Samples were collected from forty unrelated Iraqi families of various genders stored in sealed paper envelops within a period 2-3 weeks at room temperature before extraction time. Hair samples collected with length of 10$12 \mathrm{~cm}$ from the hair follicle. Each sample were divided into two parts, first part with hair follicle (root) and the second contained only hair shaft, each hair part treated as an individual samples. The collection included history information of age, sex, ancestry information, type of hair dyes treatment (with some other considerations like graying hair). Collected hair samples from male and children considered as the control group for non-treated hair. All the collected samples washed by immersing them in distilled water to remove the surface dirt and other contaminants.

\section{DNA Extraction:}

\section{Phenol-chloroform protocol (organic)}

This method was conducted based on our previous study [16] with the addition of an extra amount $20 \mu$ Lof 1 Mof Dithiothreitol (DTT) to the lysis buffer which consist of [10 mMTris HCL (pH 8.0), $10 \mathrm{mM}$ EDTA, $50 \mathrm{Mm}$ $\mathrm{NaCl}, 2.0 \% \mathrm{SDS}$ ] add $500 \mathrm{ml}$ to the hair sample followed by $15 \mu \mathrm{L}$ of $10 \mathrm{mg} / \mathrm{mL}$ proteinase $\mathrm{K}$, mix gently. Incubation at $56^{\circ} \mathrm{C}$ for 6-8 hours after incubation vortexes, and an additional 20- $\mu \mathrm{L} 1 \mathrm{M}$ DTT and $15 \mu \mathrm{L}$ of 10 $\mathrm{mg} / \mathrm{mL}$ proteinase $\mathrm{K}$, mix gently, re-incubate at $56^{\circ} \mathrm{C}$ for $6-8$ hours until hair completely dissolved and the producer completed as the traditional method.

\section{Commercial kit}

Prep Filer Magnetic is a forensic DNA extraction kit and this protocol is carried out according to manufacturer instructions [17].

\section{Gel electrophoresis}

The integrity of genomic DNA was assessed by electrophoresis on a $0.8 \%$ agarose gel, followed by visualization with Diamond TMNucleic Acid staining dye. Agarose gel electrophoresis (2\%) was performed after PCR amplification and after the first purification step.

\section{Quantification of extract DNA}

The yield of extracted DNA quantified by real time PCR specific gene detection (stander curve Taq man technique) with the commercial kit (Quntifiler $®$ Human DNA quantification kit) in 7500 Fast Real-Time PCR System, 7500 SDS software. This quantification method was used because compounds such as RNA, melanin and aromatic amines present in hair dyes.

\section{Amplification of HV1}

Amplification target of our PCR was hypervariable Region (HV1) in D-loop of mitochondrial DNA (342bp) the primers sequence of forward and reverse used as following:

\section{L15933: 5' - CAGTCTTGTAAACCGGAGATG-3' H16401: 5'-TGATTTCACGGAGGATGGTG -3'}

The reagents and their amounts which we used to amplify HV1 segment, all explained in Table (1) that includes PCR reagents and PCR amplification program. 
Table (1): a. Is representing the reagents and their amount. b. Is representing PCR amplification program a. PCR Reagent

\begin{tabular}{cc}
\hline Reagent & Quantity $(\mu \mathrm{l})$ \\
\hline Master mix gold 10X & 12.5 \\
primer $(10$ picomole $/ \mu \mathrm{l})$ & 1 forward primer \\
forward and reverse & 1 reverse primer \\
Deionized water & 7.5 \\
DNA template & 3 \\
Final Vol & 25 \\
\hline
\end{tabular}

b. PCR Cycling

\begin{tabular}{ccc}
\hline $\begin{array}{c}\text { PCR } \\
\text { conditions }\end{array}$ & ${ }^{\circ} \mathrm{C}$ & Time \\
\hline Hold & $\mathbf{9 5}^{\circ} \mathrm{C}$ & 12 min \\
& ${95^{\circ} \mathrm{C}}^{1}$ min \\
35 cycles & $\mathbf{5 6}^{\circ} \mathrm{C}$ & 1 min \\
& $\mathbf{7 2}^{\circ} \mathrm{C}$ & 1 min \\
Hold & $\mathbf{7 2}^{\circ} \mathrm{C}$ & 10 min \\
Hold & $4^{\circ} \mathrm{C}$ & Forever \\
\hline
\end{tabular}

\section{Purification}

Purification was carried out by using Qiagen MinElute PCR Purification Kit according to the manufacturer's instructions [18]. Purification was done after the first amplification and another one after cycle sequence amplification.

Cycle Sequencing (Sanger method)

DNA sequencing performed each in separated test tube, the forward strand and reverse strand and the reaction mixes down as follows Table (2)

Table (2): a. It represents the reagents and amount of Sequence reaction mix b. It represents Sequence amplification program.

\begin{tabular}{cc}
\multicolumn{2}{c}{ a. Sequence reaction mix } \\
\hline Reagent & Quantity $(\mu \mathrm{l})$ \\
\hline Big Dye Terminator v3.1 & 8 \\
primer (10 pmole/ $\mu \mathrm{l})$ & \\
(forward or reverse) & 1 \\
Deionized water & 7 \\
PCR purified & 4 \\
Final Vol & 20 \\
\hline
\end{tabular}

\begin{tabular}{ccc}
\multicolumn{3}{c}{ b. PCR Cycling } \\
\hline PCR conditions & ${ }^{\circ} \mathrm{C}$ & Time \\
\hline Initial Denaturation & $95^{\circ} \mathrm{C}$ & 12 min \\
& $95^{\circ} \mathrm{C}$ & 1 min \\
35 cycles & $56^{\circ} \mathrm{C}$ & 1 min \\
& ${72^{\circ} \mathrm{C}}^{\circ}$ & 1 min \\
Hold & $72^{\circ} \mathrm{C}$ & 10 min \\
Hold & $4^{\circ} \mathrm{C}$ & forever \\
\hline
\end{tabular}

\section{Genetic analysis}

Using the plate (96 well) of genetic analyzer, purified PCR product after cycle sequence mixed with formamind 1:10 then the samples were analyzed by GeneMapper v. 3.2 software from (Applied Biosystems, Foster City,

CA, USA).

\section{Results and Discussion}

This comprehensive study was focused on extraction and sequencing of mtDNA hypervariable region (HV1) from hair sample follicles with shafts and samples include only shafts. The hair samples for both methods shown in Table (3) with age range from 2 to 65 years.

Table (3): Hair samples and successful amplification rates of each group for both methods.

\begin{tabular}{ccccccccc}
\hline Method & Follicle & \multicolumn{1}{c}{ Shaft } & Normal & \multicolumn{1}{c}{ Dyes } & Henna & Gray & Male & Female \\
\hline Organic & $\mathbf{1 0}^{*}: \mathbf{2 0}$ & $\mathbf{4}^{*}: \mathbf{2 0}$ & $\mathbf{5}^{*}: 9$ & $\mathbf{4}^{*}: 7$ & $\mathbf{0}^{*}: \mathbf{2}$ & $\mathbf{1}^{*}: \mathbf{2}$ & $\mathbf{8}$ & 12 \\
Prepfiler kit & $\mathbf{1 9}^{*}: 20$ & $\mathbf{0}^{*}: \mathbf{2 0}$ & $\mathbf{9}^{*}: 9$ & $\mathbf{6}^{*}: 7$ & $\mathbf{2}^{*}: \mathbf{2}$ & $\mathbf{2}^{*}: \mathbf{2}$ & $\mathbf{8}$ & $\mathbf{1 2}$ \\
\hline
\end{tabular}

*No: Number of successful samples amplification

Using Phenol-chloroform extraction protocol mtDNA isolated from 50\% of hair samples included follicles and this ratio was not far from the results of previous study [19]. Moreover, a successful isolation of four-hair samples shaft only, these findings were considering as an achievement in DNA extraction from human hair shafts only. It is striking that the four samples belong to children aged 2-4 years may be because the children have a fine texture of hair [20].

Naturally the hair was rich with protein (keratin) [21], requires additional steps to the shaft (no trace remains) this will give the time to release the DNA from keratinized tissue [22]. In order to liberate the DNA from hair tissue, detergents and were used [4]. The amount of DNA extracted from hair shafts was very low with reducing agents (e.g., SDS, DTT) and proteinase K in lysis buffer for at least 14 hours or overnight average $0.4325 \mu \mathrm{g}$. While the average of DNA extracted from hair follicles was $1.4005 \mu \mathrm{g}$. There were faint and sometime unobvious bands that appeared after DNA extraction by using Phenol-chloroform method due to low 
concentrations but outcome of real time PCR indicate presence of minute amount of DNA and this amount was enough to give satisfying bands after PCR amplification of HV1 Figure (1).

a

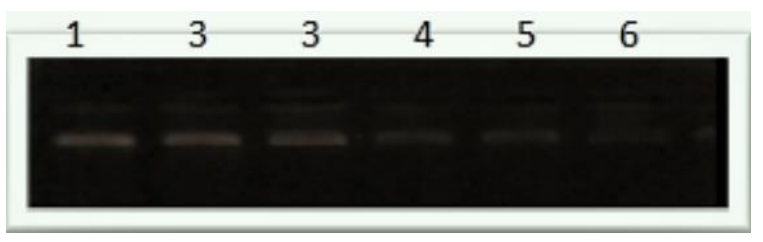

b

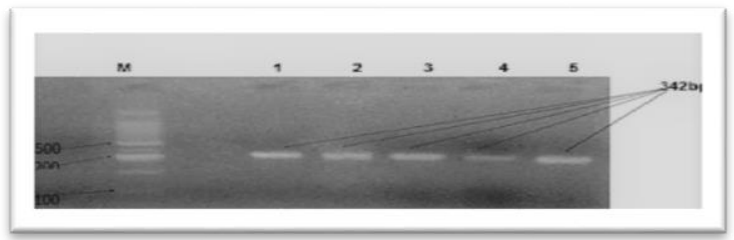

Fig. (1): a. Is representing the genomic DNA after extraction of hair samples by using organic extraction method, notice the faint bands pattern. Sample no: 6 gave no result. (Voltage70, Gel concentration: 0.8\% agarose, Time 1: hrs).

b. Is representing the DNA bands pattern of mtDNA of the same samples after PCR amplification intense of the bands depend on DNA concentration (Voltage70, Gel concentration: 2\% agarose, Time 2: hrs).

Isolation of mtDNA by using prepFiler Magnetic forensic DNA extraction kit was excellent choice to give a satisfying DNA concentration and purity for successful amplifying of mtDNA from biological hair samples including hair follicles Figure (2).

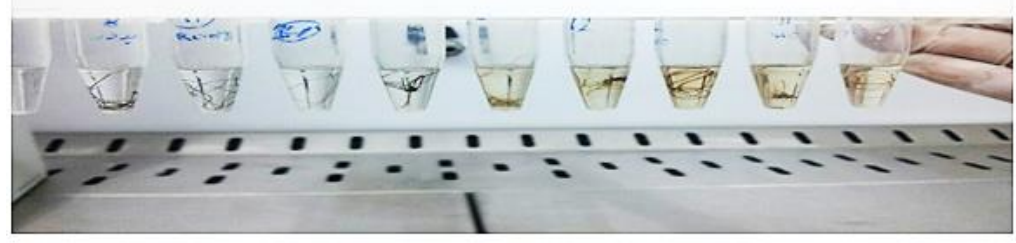

Fig. (2): Non-treated hair on the left and dyed hair samples on the right, later these dyes will interfere with sequence result (these figures represent a lysis step by using prepFiler forensic kit).

Irrespective to hair type category the average of DNA concentration was $10.917 \mathrm{ng}$, may be because its protocol suitable for most of forensic sample types including stains and swabs of body fluids [17]. A sufficient bands pattern and integrity have appeared on agarose gel after extraction of DNA and subsequently these findings have affected the of bands pattern during gel electrophoresis appearing with faint bands Figure (3)

\section{$\begin{array}{llllllllllllllllllll}1 & 2 & 3 & 4 & 5 & 6 & 7 & 8 & 9 & 10 & 11 & 1213 & 14 & 15 & 16 & 17 & 18 & 19 & 20\end{array}$}

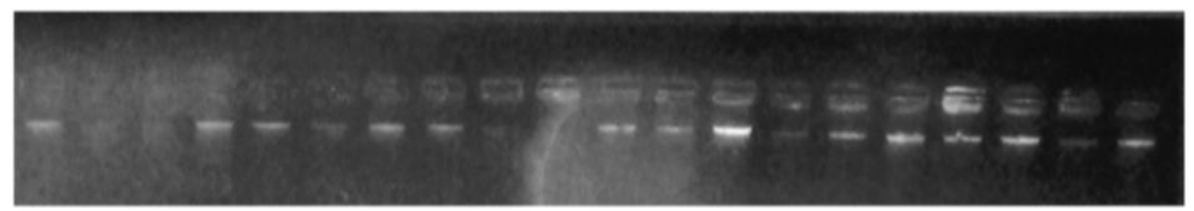

Fig. (3): Agarose Gel electrophoresis of DNA extracted from biological hair material by using prepFiler Magnetic forensic DNA extraction kit (Voltage70, Time: $1 \mathrm{hrs,} \mathrm{Gel} \mathrm{concentration:} \mathrm{0.8 \%} \mathrm{agarose).}$

MtDNA was not detectable in samples including hair shaft only (without roots) with average yield $0.029 \mathrm{ng}$, these few concentrations may be because the prepFiler kits protocol required at least two hair roots with hair shaft [5]. Time of extraction by the prepFile kit about 2 hour and this time was not enough to release DNA from keratinized tissue needed at least 14 hours or overnight [23]. Both methods revealed the discrepancy in the yield and purity among the hair samples categories, treated hair (bleached) have shown very low concentration results in contrast to non-treated hair and gray. Even the samples treated with henna (Natural herbal dyes) have shown 
higher DNA concentrations results than those colored with chemicals may be because the hydrogen peroxide (competent of hair dyeing agent) attack the bonds within DNA, as occurs for protein disulphide bonds [24].

This finding was not affected only on the result of PCR product through bands intensity appearance during gel electrophoresis, but it was also affecting the sequence results Figure (4), this figure shows low quality electropherogram of a bleached hair sample with no sequence result.

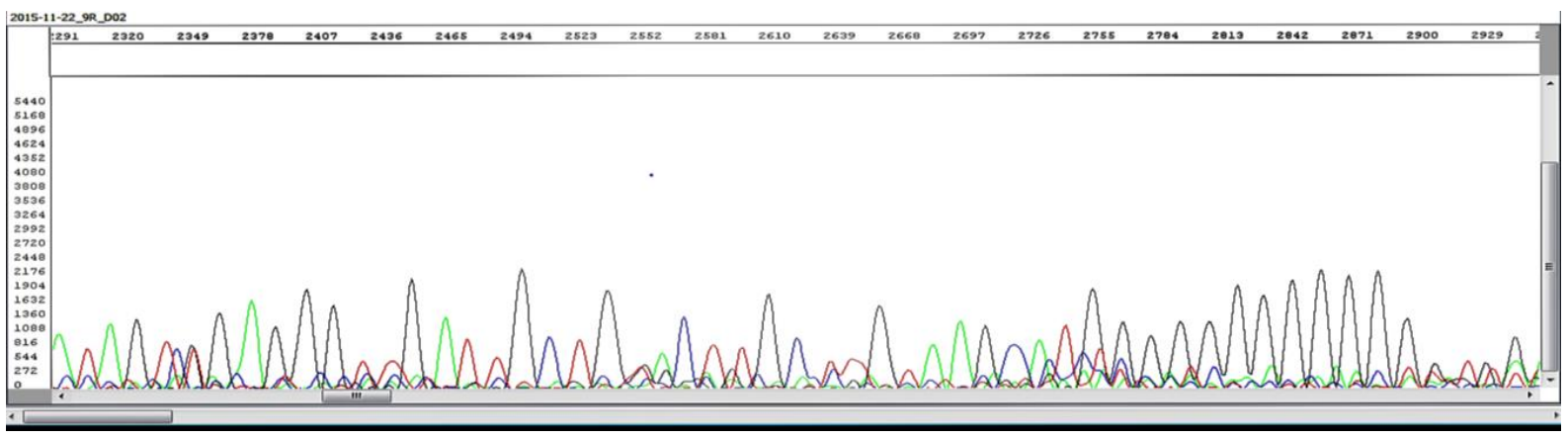

Fig. (4): Electropherogram of a bad sequence result, with low alleles call and there is an interference of base with allele's call this DNA is related to a sample of bleached hair.

We could successfully amplify such a kind of sample but it was not necessary that sequence result can be reading. After the second or third attempt of re-amplification (more extracted DNA is added) and repurification, finally we get satisfying results Figure (5). This finding may be show as that the DNA from dyed hair more degraded so we gain less DNA yield in contrast to non-treated hair, these results agrees with the Baker et al. [20].

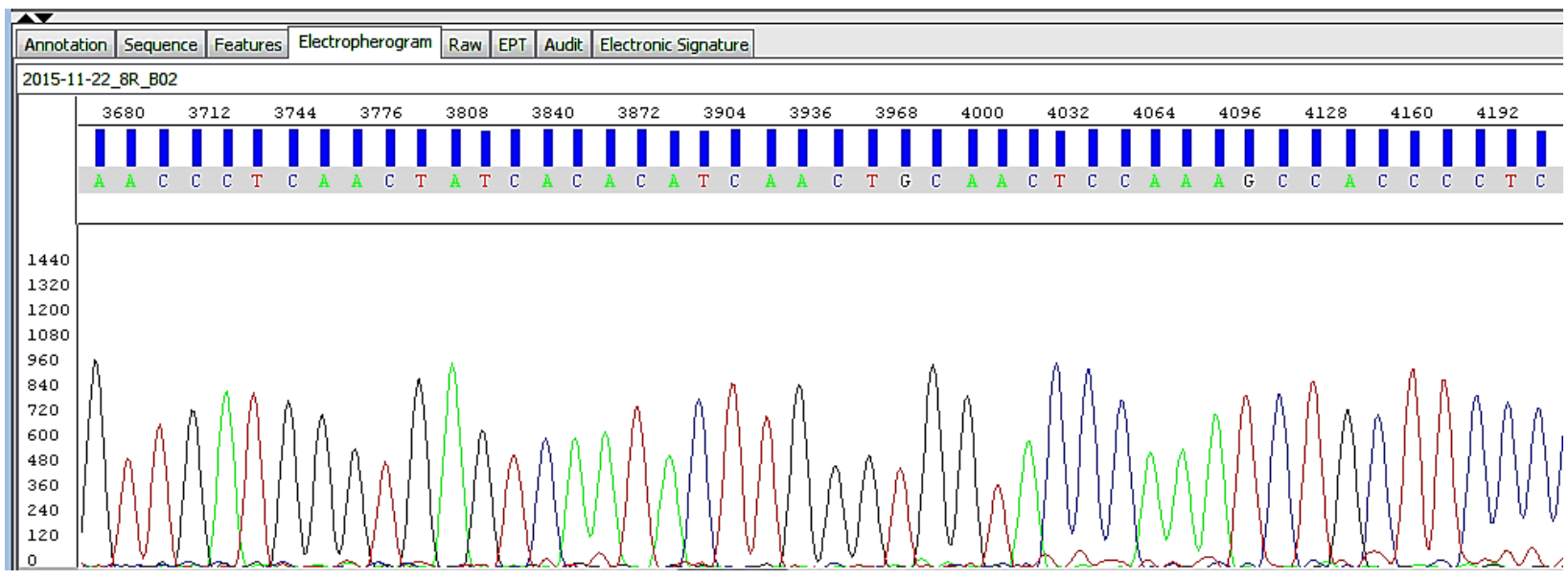

Fig. (5): Electropherogram of excellent sequence result, with successful alleles call and there is no interference of base with alleles call this mtDNA sequence is related to a male hair sample.

Samples, which did not represent good band intensity on agarose gel back to low DNA template [3,23] especially in hair shaft samples even if more extracted DNA is adding in amplification step. However, using of hair dyes also can be an influence factor, it contain PCR inhibiters like melanin and by influence of colorant treatments (hydrogen peroxide), convert water insoluble melanin to water soluble melanin and this act in the same manner as DNA during purification process and remain in DNA solution as inhibiter to PCR [4,25].

\section{References}

1. Bisbing, R. E. and Wolner, M. F. (1984). Microscopical discrimination of twins' head hair. Journal of Forensic Sciences. 29:780-786.

2. Max, M., Houck, M.A. and Bruce, B. (2002). Correlation of Microscopic and Mitochondrial DNA Hair Comparisons. J. Forensic Sciences. Vol. 47, No. 5. 
3. Nguyen, T., Dieuhoai C., Phan Tuan Phong, T.T. (2012). Extraction of Human Genomic DNA from Dried Blood Spots and Hair Roots. International Journal of Bioscience, Biochemistry and Bioinformatics. Vol. 2, No. 1,

4. Paula, F., Campos and Thomas, M.P. Gilbert. (2012). Extraction from Keratin and Chitin. Methods in Molecular Biology. 840: 43-49.

5. Higuchi, R., Von, C.H., Sensabaugh, G.F., Erlich, H.A. (1988). DNA typing from single hairs. Nature. 332: 543-546.

6. Mark, W.D., Owen, G. and Donald, O. (2006). DNA Forensics: Expanding Uses and Information Sharing. September. Sacramento. California.

7. Melton, T., Holland, C. and Holland, M. (2012). Forensic mitochondrial DNA analysis: Current practice and future potential. Forensic Science. 24:101.

8. Cary, T.O. (2009). Forensic Hair Comparison: Background Information for Interpretation. Review article. Forensic science communication. 11: 2 .on line.

9. Wilson, M.R., Polanskey, D., Butler, J., Dizinno, J.A. and Replogle, J. (1995). Extraction, PCR amplification and sequencing of mitochondrial DNA from human hair shafts. Biotechniques. 18.4:662-668.

10. Ewazie, T., Magdalena, M., Patrycja, D., Jadwiga, Ż.G., Mariusz, G., Barbara. and Michał, W. (2012).Current genetic methodologies in the identification of disaster victims and in forensic analysis . Genetics .53:41- 60.

11. Emi, S. and Hiroshi, N. (2005). Evaluation of three methods for effective extraction of DNA from human hair. Biological Chemistry. 820: 137-141.

12. Allen, M., Engstrom, A., Meyers, S., Handt, O., Saldeen, T., Haeseler, A. etal. (1998). Mitochondrial DNA sequencing of shed hairs and saliva on robbery caps: sensitivity and matching probabilities. Forensic Science. 43:453-64.

13. Rebecca, S., Just, A., Jodi, A., Irwin, C. and Walther, P. (2015). Mitochondrial DNA heteroplasmy in the emerging field of massively parallel sequencing. Forensic Science International Genetics 18 .131-139.

14. Templeton, J., Brotherton, P., Lamas, B., Soubrier, J., Haak, W., Cooper, A., et al. (2013). DNA capture and next-generation sequencing can recover whole mitochondrial genomes from highly degraded samples for human identification. Investigative Genetics. 4:26.

15. Anderson, T.D., Ross, J.P., Roby, R.K., Lee, D.A. and Holland, M.M. (1999). A validation study for the extraction and analysis of DNA from human nail material and its application to forensic casework, J. Forensic Sci. 44 .1053-1056.

16. Al-Sammarraie, H. K. I. (2016). Comparison between Two Different DNA Extraction Techniques Taken from Buccal Swabs Suitable for Genetic Analyzer. Journal of Al-Nahrain University.19 (3):108-113.

17. User's manual. (2008). prepFiler ${ }^{\mathrm{TM}}$ forensic DNA extraction kit user guide, Applied Biosystems, USA.

18. Handbook. (2008). MinElute PCR Purification Kit For purification of PCR products ( 70 bp to $4 \mathrm{~kb})$ in low elution volumes.

19. Linda Vigilant. (2008). An Evaluation of Techniques for the Extraction and Amplification of DNA from Naturally Shed Hairs. Biological Chemistry. 380:1329 - 1331.

20.Lori, E., Baker, M.A., William, F., McCormick, M.S., M.D. and Karla, J.M. (2001). Silica-Based Mitochondrial DNA Extraction Method Applied to Forensic Hair Shafts and Teeth". Forensic Science. 126-130.

21.Xiong, W., Ying, S., Qiong, Z., Xiaoming, L., Shizheng, X. and Tiechi, L. (2012). Detailed histological structure of human hair follicle bulge region at different ages: A visible niche for nesting adult stem cells. Huazhong University of Science and Technology. 32.5:648-656.

22. Barbara, B., Fabio, R., Mauro, L., Elisabetta, S., Anna, T., Elena, G. Rita, R. and Luigi F. (2013). The human hair: From anatomy to physiology. International journal of dermatology. 53:3.

23.Alberts, C.C., Ribeiro-Paes, J.T., Aranda-Selverio, G., Cursino-Santos, J.R., Moreno-Cotulio,V.R., OliveiraA.L.D., Porchia, B.F.M., Santos, W.F. and Souza, E.B. (2010). DNA extraction from hair shafts of wild Brazilian felids and canids .Genetics and Molecular Research. 9 (4): 2429-2435.

24. Daniell, A.M.A., Richard, S. and Paul, A. Cornwell. (2003). Analysis of DNA in hair fibers. Cosmetic Science. 54: 21-27.

25.Emi, S. and Hiroshi, Nakamura. (2005). Evaluation of three methods for effective extraction of DNA from human hair. Chromatography. 82:137-141. 